\title{
The arthritic in an urban environment
}

\author{
M. ANNE CHAMBERLAIN, JEAN M. BUCHANAN, AND HELGA HANKS \\ From the Rheumatology Research Unit, School of Medicine, University of Leeds
}

SUMMARY Ninety-five patients with rheumatoid arthritis or osteoarthrosis were interviewed and questioned in their homes, being randomly selected from 354 outpatients with these diseases. The findings were compared with answers from 30 matched able-bodied controls. The handicapped were mainly female and elderly; over half were severely or appreciably handicapped; nearly one-third lived alone. The average weekly income of these households was $£ 25$, at least $£ 6$ a week less than their age-matched counterparts. Very few subjects lived in adapted or specially designed housing, and half the housing had at least 2 steps to street level. A third of the sample could not walk more than 10 yards $(9 \mathrm{~m})$, and only half could walk 100 yards $(90 \mathrm{~m})$; yet only one-third had a bus stop, one-quarter a local park, and one-third a local shop within this distance. One-third of the patients could not shop for themselves. Powered wheelchairs were not used. Buses were rarely or never used by nearly half these arthritics because of severe disability. Cars were owned by less than a quarter of the sample, and only by those financially better off. Over a third were unable to get a lift when wanted. Cars ameliorated much of the frustration and lack of social contact caused by physical disability. Adequate financing would enable those with severe disability to engage in normal activities. Better designed buses stopping nearer the homes of handicapped would improve independence for those less severely disabled. Correct siting of mobility housing, shops, community facilities, and parks would be greatly appreciated, as would removal of all unnecessary steps and kerbs.

It can be expected that arthritics like others in the community will wish to be involved in its life and will need to be mobile. A recent leading article British Medical Journal (1978) suggested that provision for the mobility of the physically handicapped is less than adequate, yet few data are available on the level of mobility achieved by them, particularly in relation to diagnosis and level of functional handicap.

Mobility in most forms of chronic arthritis is impaired, but the extent of the impairment in such terms as the distance travelled in the normal suburban environment (and the consequent use made of this area) on foot is unknown. Not is the patient's use of public transport or his access to private transport documented.

In a society where individual independence is valued highly, perhaps more so than mutual dependence, possible reduction in individual mobility caused by the interaction of disease with the patients'

Accepted for publication 21 April 1978

Correspondence to Dr M. Anne Chamberlain, Rheumatism Research Unit, School of Medicine, 36 Clarendon Road, Leeds LS2 9PJ. physical environment will have profound effects on life style and the pursuit of individual aims.

The present interview survey was designed to provide information on the mobility and independence of a defined group of people suffering from rheumatoid arthritis and osteoarthrosis living in a well circumscribed provincial urban area, namely, Leeds. This report delineates the characteristics of the group studied in terms of severity of disability, suitability of housing and its siting, and finance, as a person's mobility cannot be considered without a knowledge of his environment and the resources which he may command in its utilisation.

\section{Materials and methods}

\section{SAMPLE COMPOSITION}

Three hundred and fifty-four outpatients with rheumatoid arthritis or osteoarthrosis were identified from hospital records. They were classified (by postal questionnaire) into 5 groups according to disability, and also into 3 groups according to the housing in which they lived (numbers in each category in final sample shown in parentheses). 
Degree of disability. 1) Fully employed/employable, normal recreation (90). 2) Light work or part-time work (limited physical recreation (all housework except the heaviest (26) ). 3) Not employed/employable (light housework and limited shopping (67)). 4) Confined to house or wheelchair (able to look after himself in the essentials of life (16) ). 5) Chairfast/bedfast (needing special care and attention (1)).

Type of housing. 1) Post war (1950s on-34). 2) Interwar (1920s and 1930s-52). 3) Prewar (pre 1914-34).

\section{SELECTION OF SAMPLE}

Of the 354 persons identified, 120 attending rheumatology outpatients at Leeds General Infirmary or St James's Hospital, Leeds, aged 16 years and over, and living at home within the boundaries of the Leeds Metropolitan area were asked to take part in the survey, having been randomly selected on the basis of the above two criteria, that is, very nth person was chosen in each disability group. The total numbers in each group were in proportion to the total universe. In the event, 95 persons were interviewed and a completion rate of $78.3 \%$ was obtained. Care was taken to ensure that within each of the functional grades, 1-4, the 3 types of housing were proportionately represented. The only person in the chairfast/bedfast group, 5, was surveyed. A further 30 non-handicapped persons acted as a control group, a quota sample being chosen to match the distribution of age, sex, and housing type of the main sample.

\section{METHOD OF INTERVIEW}

A small pilot study of 12 persons was undertaken to eliminate ambiguities in the formulation of the questionnaire. The arthritic patients selected for interview were contacted by a second letter to arrange for the trained interviewer to interview the respondent at home.

\section{MEASUREMENT OF HANDICAP}

Several measures are available; 3 were used in this survey; 1) the functional grades referred to above (Duthie et al., 1961), in common use clinically; 2) those devised by Amelia Harris (1971) and based on the answers to a number of standard questions on performance of common selfcare and domestic functions; 3) those devised by Jeffreys et al. (1969), used in conjunction with (2) and which consisted of a series of standard, reproducible, but time-consuming physical tests of performance and endurance.

For the purposes of correlating data with functional ability it was considered that the Amelia Harris categories should be used throughout, as they were understood not only by those in the clinieal field but also by those responsible for social services and those involved in urban and domestic planniz̄ and design. It is also probable that much of the information on arthritis in the various Amelia Hareis categories is applicable to those with other disabi仿ties in the same category of handicap.

\section{Results}

\section{DEMOGRAPHIC CHARACTERISTICS}

Women constituted $85 \%$ of the sample, $46 \%$ gf them being over the age of 64 . Only $1 \%$ of the respondents were under 30 years of age and only $15 \%$ under 50. The age range of the control group wis similar, but there was a higher percentage of women $(90 \%)$, and more of the control group were under 50 years of age $(30 \%)$.

Over half the respondents $(59 \%)$ were married the remainder evenly divided between widowed and single status. Three-quarters of the widowed wepe over 65 years, as were half the single respondents. The spread of married, single, and widowed people was similar in the control group, but many of the single people were in the younger age group.

\section{HEALTH STAT US}

The group was made up of almost equal numbers of patients with rheumatoid arthritis and osteoarthros $\bar{B}$; $4 \%$ of patients had developed the latter on the bas of the former.

Over three-quarters of the sample had had art $\overrightarrow{\overline{\mathrm{A}}}-$ ritis for at least 5 years, and nearly one-half had nêt it for over 10 years. Those of retiring age tended have been affected longer, two-thirds having haid arthritis for 10 years or more.

Almost half the sample had other diagnosess, irrespective of whether they were severely or or thy mildly handicapped. Of the 95 interviewed, 7 had problems with hearing, 5 with sight, and 30 with othigr systems. Understandably the co-morbidity rates were slightly higher in the over-65s.

\section{HOUSEHOLD COMPOSITION}

Nearly one in three of the handicapped lived aloner, the majority of whom $(93 \%)$ were women, mostiby over the age of 65 years $(64 \%)$. Only $12 \%$ of the respondents lived in households with children unfegr 16 years; of these, in every case except 1 , it was the mother who was disabled. Figures from the control group were similar. Nearly one-third of the severefy handicapped and just under one-half of the appireciably handicapped lived alone.

WORKING STATUS AND INCOME Only $18 \%$ of the arthritics were working, and 8 ff 
these slightly more than half worked part-time; most of these were in the 30-64 years age range. Most of the remainder were housewives or retired, and only 9 were unemployed or off sick. In the control group half were housewives or retired, 11 were in work, 2 were students, and 1 was off work.

The arthritic patients were financially substantially worse off than their normal counterparts matched for age. One in 2 of all handicapped persons was living on an income of less than $£ 30$ per week per household including supplementary benefits. The national average weekly household income in 1975 was $£ 58 \cdot 15$, yet only $12 \%$ of the handicapped households received $£ 30$ or more. Average weekly income for those below 65 years in the sample were approximately $£ 50$. For those over the age of 65 in the sample the average was $£ 25$, compared with the national average for the retired of $£ 31 \cdot 33$.

\section{HOUSING AND FACILITIES}

The majority of those with arthritis lived in houses rather than flats or bungalows. Even the majority of severely handicapped lived in standard housing. The more severely handicapped were more likely to live in local authority housing ( $41 \%$ ), but a small proportion $(8 \%)$ live in privately rented housing, where modifications may often be made only with difficulty. $20 \%$ of the severely or appreciably handicapped lived in pre-1914 housing, which is usually associated with more steps to the street and fewer facilities. Ramps or lifts were generally found in postwar housing, but even then these were available for only a tenth of those in such accommodation. Few houses had a downstairs toilet, and only onequarter of the respondents had central heating, compared with $47 \%$ of controls. $14 \%$ of arthritics had no telephone compared with $3 \%$ of controls.

\section{DEGREE OF HANDICAP}

Since respondents were culled from those attending hospital outpatients those in Amelia Harris's most severely handicapped groups (1-3) were not encountered. The distribution of handicap by age and severity is shown in Table 1 . Over a third of the handicapped were severely handicapped (Amelia Harris categories 4 and 5), and another fifth were appreciably handicapped (Amelia Harris category 6). These 2 groups constituted over half the sample and affected predominantly the more elderly. Respondents in categories 7 and 8 were described in the national survey as having minor or no handicaps and in our survey were usually employed, functional grade 1. Yet even these people encountered problems during their day-to-day activities and found walking along pavements, negotiating kerbs, carrying shopping, and getting to the bus difficult.
Table 1 Degree of handicap by age

\begin{tabular}{lllll}
\hline & $\begin{array}{l}\text { Total no. } \\
\text { of } \\
\text { patients } \\
(95)\end{array}$ & $\begin{array}{l}\text { Aged 64 } \\
\text { and } \\
\text { under } \\
(53)\end{array}$ & $\begin{array}{l}\text { Aged } \\
65-74\end{array}$ & $\begin{array}{l}\text { Aged } \\
75+\end{array}$ \\
\hline $\begin{array}{l}\text { \% at each disability } \\
\text { level }\end{array}$ & & & & $(12)$ \\
\hline $\begin{array}{l}\text { and 5: Severely } \\
\text { handicapped }\end{array}$ & 35 & 32 & 40 & 33 \\
$\begin{array}{l}\text { 6: Appreciably } \\
\text { handicapped }\end{array}$ & 19 & 15 & 17 & 42 \\
$\begin{array}{l}\text { 7: Minor handicap } \\
\text { 8: No apparent }\end{array}$ & 25 & 25 & 26 & 25 \\
handicap & 21 & 28 & 17 & - \\
\hline
\end{tabular}

Figures in parentheses refer to actual number of subjects studied. For definition of categories of handicap 4-8 see Harris (1971).

\section{ATTIT UDE TO DISABILITY}

The question proved a useful talking point for respondents but was difficult to analyse. A third were discontented and missed active hobbies or were lonely. About a quarter professed general contentment, but a similar number had mixed feelings. Younger people were more active socially. Those in middle age (50-74) were most discontented. The most discontented of all were the most disabled, the most housebound with fewest contacts. The less disabled, the more mobile people were; the more social contact they had, the less frustration was felt against their arthritis. Although doctors prescribed analgesics to almost all patients, pain was felt to be a disadvantage by only $12 \%$, but loss of mobility was resented by over half the patients.

\section{USE OF AIDS AND ASSISTANCE}

Of the nine-tenths of the handicapped able to get out of the house half needed aids or an assistant or both, particularly the older women. Assistance was more usual than an aid, particularly among men; those living alone were forced to rely most heavily on mechanical aids. Only 5 people used a wheelchair, and 2 of these were housebound; no powered wheelchairs were in use.

\section{MOBILITY ON FOOT}

There was a great variation in the distance respondents could comfortably walk without pausing (Table 2). Thus 1 in 3 respondents could not walk beyond their gate ( 1 in 2 of these aged 75 and over), and 1 in 2 could not walk further than 100 yards $(90 \mathrm{~m})$. In most cases walking ability conformed with the severity of the handicap, and aids or assistance were used by most people who were unable to walk more than 50 yards $(45 \mathrm{~m})$.

Only one-third of the handicapped were able to walk more than a quarter of a mile $(400 \mathrm{~m})$, and yet many housing areas do not contain a shop or park within this distance. Nearly one in three respondents 
Table 2 The mobility of handicapped people on foot: percentages at various levels of mobility

\begin{tabular}{|c|c|c|}
\hline & $\begin{array}{l}\text { Handicapped } \\
\text { of all ages (95) }\end{array}$ & $\begin{array}{l}\text { Handicapped } \\
\text { aged } \geqslant 75 \mathrm{yr} \\
\text { (12) }\end{array}$ \\
\hline 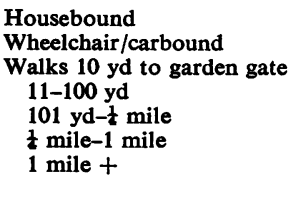 & $\begin{array}{c}10 \\
6 \\
13 \\
19 \\
23 \\
14 \\
15 \\
100 \%\end{array}$ & $\begin{array}{c}17 \\
8 \\
25 \\
8 \\
34 \\
8 \\
- \\
100 \%\end{array}$ \\
\hline
\end{tabular}

* 48\% all handicapped can walk only 100 yards or less.

$\dagger 50 \%$ of handicapped $\geqslant 75 \mathrm{yr}$ can walk only 10 yards or less. 100 yards $=90 \mathrm{~m} ; \mathrm{t}$ mile $=400 \mathrm{~m}$.

could not walk to their nearest shop in comfort, a quarter were unable to reach the nearest bus stop without difficulty, and nearly two-thirds were unable to reach a park.

DIFFICULTIES ENCOUNTERED WHEN WALKING Inside buildings. Over half the sample had difficulty managing 10 stairs or less; $51 \%$ used both lifts and escalators, $17 \%$ lifts alone, $5 \%$ escalators alone, and $27 \%$ could use neither. The normal reasons given for this were that the patients found difficulty or were frightened of the lifts and escalators.

Outside buildings (external features). Numerous problems were encountered: uneven surfaces were mentioned by $73 \%$ and steep slopes by $68 \% .60 \%$ found difficulty in mounting and descending kerbs, which are normally unavoidable. Almost half could not cross roads with ease. The most severely affected patients had most problems in relation to their environment. Of the control group only the elderly and those pushing a pram encountered problems. Rain, snow, and ice made walking hazardous for half the respondents, whereas only $3 \%$ control group had any difficulty in poor weather.

\section{VEHICULAR TRANSPORT}

Less than 1 in 5 of the sample had a car, compared to over one-third of controls, and nearly half did not use public transport. All controls were able to use public transport.

Public transport. In Leeds buses, often doubledecker, were the normal form of transport (Table 3), very few of either the handicapped or control samples using the shoppers' bus, trains, or taxis. Most of those who did not use public transport were at least appreciably handicapped. People in older accommodation, flats and terraced or backto-back housing formed the majority using buses.
Table 3 Use of public transport by degree of handicap $\frac{\text { ㅁ. }}{\text {. }}$

\begin{tabular}{|c|c|c|c|c|c|c|c|}
\hline \multirow[b]{2}{*}{ Total } & \multirow[b]{2}{*}{$\begin{array}{l}82 \\
\%\end{array}$} & \multirow{2}{*}{$\begin{array}{l}\text { Severely } \\
\text { handi- } \\
\text { capped } \\
\text { (cat. } \\
4 \& 5) \\
20 \\
\%\end{array}$} & \multirow{2}{*}{$\begin{array}{l}\begin{array}{l}\text { Appre- } \\
\text { ciably } \\
\text { handi- } \\
\text { capped } \\
\text { (cat. 6) }\end{array} \\
18 \\
\%\end{array}$} & \multirow{2}{*}{$\begin{array}{l}\begin{array}{l}\text { Minor } \\
\text { handi- } \\
\text { cap } \\
\text { (cat. } 7)\end{array} \\
\begin{array}{l}24 \\
\%\end{array}\end{array}$} & \multirow{2}{*}{$\begin{array}{l}\begin{array}{l}\text { No } \\
\text { apparent } \\
\text { handicap } \\
\text { (cat. 8) }\end{array} \\
20 \\
\%\end{array}$} & \multicolumn{2}{|c|}{ 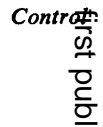 } \\
\hline & & & & & & $\begin{array}{l}30 \\
\%\end{array}$ & \} $\\
{\hline \begin{array}{l}\text { Use of } \\
\text { standard } \\
\text { buses }\end{array}} &{ } &{ } &{ } &{ } &{ } &{ } &{\overrightarrow{0}} \\
{\hline \text { Yes }} &{54} &{25} &{44} &{75} &{65} &{93} &{1} \\
{\hline \text { Rarely }} &{8} &{5} &{6} &{12} &{10} &{\text { - }} &{\omega} \\
{\hline \text { Never }} &{38} &{70} &{50} &{13} &{25} &{7} &{\text { ద }} \\
$\hline
\end{tabular}

* 3 respondents did not answer the section on public transport.

The frequency with which buses wee used depended heavily on the severity of the disability, only onethird of the severely handicapped travelling by bus more than once weekly. The difficulties most fred quently encountered are associated with getting of or off the vehicle and with maintaining a hold whife it accelerated. None of the controls experienced any difficulties.

Private transport. Only one-third of the handicapped unable to use the bus had access to a car, and on one person owned an Invacar. Car ownership was correlated with high income and modern housing; income and car ownership were much lower in the handicapped group. Only $16 \%$ of the handicapped drove, less than half the number of drivers in trae control group. Although 39\% were taken out regularly and a further $8 \%$ managed to obtain the occe sional lift, over one-third were unable to get a lift at all, compared with $7 \%$ in the control group. whi could all use buses. In both groups the older peopte were worse off, less likely to own a car or obtain lift, and handicapped men were much worse off thaig men in the control group, all of whom had a car.

\section{SHOPPING}

Only 1 in 3 arthritics shopped alone, and another third managed some of their shopping but needend someone to help with transport or with carrying? This left one-third entirely dependent on otheng to shop for them.

Over one-third of pre-1914 housing was withw 50 yards $(45 \mathrm{~m})$ of the nearest shop, and nearly haff was within 100 yards $(90 \mathrm{~m})$. In contrast, less tha one-third of the newer housing was within 100 yards $(90 \mathrm{~m})$ of the neighbourhood centre. How ever, other factors entered here, as older housing contained a lower proportion of heavily handicapped people. Marked differences were found in the use of local shops, neighbouroood shopping centres and 
community facilities between the study group and controls. Thus, whereas $43 \%$ of controls went to the baker daily, a similar proportion of the arthritics never went. Similarly, $70 \%$ of controls went to the post office weekly, $43 \%$ of arthritics never went. Patients complained of the arduous journey to the shops of queuing, and of difficulty in handling money and carrying shopping. They did not confine shopping to small shops but liked the personal service there and the way in which these shops acted as meeting places. $20 \%$ had mobile shops visit the home.

\section{OUTSIDE CONTACT}

While $97 \%$ of control subjects had contact with others at least daily, over one-third of the handicapped saw fewer than 2 or 3 people a week. Even walking 10 yards $(9 \mathrm{~m})$ increased the frequency of contact compared with the housebound (Table 4), and frequency of contact parallelled the ability to walk.

Nearly two-thirds of arthritics had both friends and relations living in Leeds, a figure only slightly lower than the control group. Friends lived nearer than relatives, but only two-thirds of the friends of the severely handicapped lived within 5 minutes and $20 \%$ lived over half an hour away. Pre-1914 housing seemed more sociable, visits from relatives averaging once a day compared with only twice or three times weekly in newer housing. Well over a third of the arthritics entertained friends and relations only at home. Many said they disliked being dependent on friends calling to see them as it affected the quality of the relationship.

The terms clubs and societies were taken to include a variety of organisations, religious, political, and other, and including churches, pubs, and handicapped and old people's clubs. Just over half the arthritics were members of such organisations, and over half of these were members of the local church. Political societies and women's guilds accounted for $16 \%$, and handicapped and old people's clubs for $8 \%$ and $10 \%$ respectively. Membership of clubs declined with decreasing income, increasing handicap, and increasing age, except the 65-74 year group. $86 \%$ of those who drove belonged to societies as opposed to $49 \%$ of nondrivers, a difference not observed in the control group. $71 \%$ of those who belonged to no organisation attributed this to their arthritis and the remainder to age.

\section{LEIS UR E}

$44 \%$ of the respondents felt their arthritis restricted their leisure travel, and frustration was greatest among the most severely handicapped. Those with lowest income who were unable to drive were the most restricted.
Table 4 Frequency of contact with other people outside the house by mobility

\begin{tabular}{|c|c|c|c|c|c|c|}
\hline \multirow[b]{2}{*}{ Total } & \multirow[b]{2}{*}{$\begin{array}{l}95 \\
\%\end{array}$} & \multirow{2}{*}{$\begin{array}{l}\text { Housel } \\
\text { carbound } \\
\text { and } \\
\text { wheel- } \\
\text { chair } \\
\text { users } \\
15 \\
\%\end{array}$} & \multirow{2}{*}{$\begin{array}{l}\text { Less } \\
\text { than } \\
11 \text { yd }\end{array}$} & \multirow{2}{*}{$\begin{array}{l}\text { Can walk: } \\
11 \text { yds- } \\
1 \text { mile } \\
\\
\begin{array}{l}40 \\
\%\end{array}\end{array}$} & \multirow{2}{*}{$\begin{array}{l}\text { t mile } \\
\text { and over }\end{array}$} & \multirow{2}{*}{$\begin{array}{l}\text { Control } \\
\\
\\
\begin{array}{l}30 \\
\%\end{array}\end{array}$} \\
\hline & & & & & & \\
\hline \multicolumn{7}{|l|}{$\begin{array}{l}\text { Meeting } \\
\text { people: } \\
\text { Several times }\end{array}$} \\
\hline $\begin{array}{l}\text { a day } \\
\text { Once a day } \\
\text { 4-5 times }\end{array}$ & $\begin{array}{l}17 \\
33\end{array}$ & $3 \overline{3}$ & $\begin{array}{l}17 \\
33\end{array}$ & $\begin{array}{l}13 \\
33\end{array}$ & $\begin{array}{l}33 \\
33\end{array}$ & $\begin{array}{l}(17) \\
(80)\end{array}$ \\
\hline $\begin{array}{l}\text { a week } \\
\text { 2-3 times }\end{array}$ & 15 & 27 & 8 & 12 & 15 & (3) \\
\hline a week & 21 & 20 & 33 & 22 & 15 & \\
\hline Once a week & 10 & 20 & - & 12 & 4 & \\
\hline Less often & 4 & - & 8 & 7 & - & \\
\hline
\end{tabular}

10 yards $=9 \mathrm{~m} ; \ddagger$ mile $=400 \mathrm{~m}$.

The main pastimes of the arthritic groups were inactive and rarely involved others, $48 \%$ giving watching TV as their main pursuit, $46 \%$ reading and $35 \%$ sewing. In spite of the wording of the questions most of the handicapped listed housework as a hobby. Over half the controls undertook outdoor activities such as sport, walking, or gardening. Only $13 \%$ of arthritics did voluntary work, but a wide variety was cited-Samaritans, meals on wheels, professional society, or committee.

Only $36 \%$ of arthritics went out of the house once a day, compared with $97 \%$ controls. Age and worsening handicap affected the frequency with which arthritics got out, but age made little difference to the controls. Nearly three-quarters of those able to drive went out at least daily, and those in older housing went out considerably more frequently than their counterparts in housing built after 1920.

\section{Discussion}

The main characteristics of this group are similar in several ways to the physically disabled in the national survey (Harris, 1971); the handicapped are predominantly elderly and female, and in spite of often severe disability frequently live alone.

Few of the arthritics worked fulltime, and their income was correspondingly low, some $£ 6.08$ per week below that of their contemporaries. With 1 in 2 of arthritic households having a weekly income of less than $£ 30$ it is not surprising that the possession of central heating, telephones, and cars is lower than in the general population. Many of the sample were too old for the mobility allowance. Few concessions to disability, such as a downstairs toilet, had been 
made, and unless adaptations were to be undertaken by social services there would have been no available funding. In some cases a house was underutilised as the arthritic lived on 1 floor; both the patient and another family could have benefited from rehousing. It is therefore sad to find a recent report (Eversley, 1977) indicating that current planning in both the public and private sector takes little hold of the needs of the disabled, elderly, or those with poor finances.

There is little to suggest that those patients have consumed vast resources. Though some were in receipt of modest local authority services (Chamberlain and Buchanan, in press) few used wheelchairs; powered wheelchairs would certainly have been helpful to some but none had been supplied. The arthritic interviewed in a clinic is rarely able to give a succinct account of how chronic disease has changed his life. Yet a common pattern of disadvantage has been found in this and other studies (Thompson et al., 1974), which it is the duty of the clinician to help reverse where possible.

Over the present century developments in public health, health care, and contraceptive practice have led to an increasingly elderly population prone to arthritis. At the same time improved antiarthritic therapy both drug therapy and total care, has led to a lessening need for institutional care, so that more arthritics live at home. Fashions in house building, public and private, have changed. Terraced housing was replaced in the 1950s by spacious developments of houses remote from the town centre, rarely bungalows or purpose-built disabled units, and the 1960s saw the decline of and fall high-rise flats. Old communities have been disrupted and replaced by new estates, often built on the assumption that all of those living there have access to a car.

The present study indicates that people in older accommodation have easier access to shops of various kinds and more contact with their neighbours. Shops on new estates are often few, for they run at a loss and cannot offer their customers competitive prices. The result of their demise is that disabled people, such as the arthritic, lose yet another facet of their independence and cannot make their own decisions on such basic choices as their own clothing and food.

People who live in dense older communities are disadvantaged in terms of mobility. They are often unable to afford a car and cannot get lifts when they choose. Public transport, as it now exists, is of little use to them as they cannot get on it. Yet Brooks (1974) has shown that relatively simple and cheap alterations to bus design-lowering the steps and improving grab rails-will allow some 2 million disabled and elderly people access to this form of transport. Those denied transport have few outings, participate less in (usually nonhandicappe clubs and societies, and are forced to entertain friends only when the latter agree to call. Agair independence is reduced. However, those who hat cars differed little from controls in their participation in society.

There is no reason to suppose that the situation arthritics differs substantially from that of people with neurological lesions in whom intellect is preserved. All need improved mobility to participat in the life of the society around them. Currem solutions to the problem are satisfactory only when the patient has his individual (perhaps adapteds car. If this is not financially feasible for all those whose physical handicap results in considerable immobility, then more imaginative and flexible forms of public transport must be devised, perhaps on Scandinavian principles. Where the problem can be overcome by the provision of wheelchairs, powere or not, the mobility allowance and advice on the suitability and adaptability of various cars, the physician must be able to provide such information and help for his patient.

The authors are greatly indebted to the following: Profess V. Wright, Dr M. Jeffreys, and Dr J. Golding, whose patients were studied; Dr Williams and Mr E. Allen, who providext controls; Mrs B. Gordon, Mrs J. Packter, Mrs C. Stewaf Morgan, and $\mathrm{Mr} \mathrm{N}$. Burgess, who were responsible for secretarial and clerical work; Mrs Paula Hiscock, who an lysed an enormous amount of computer data; and Dr P. Bacon for his help in discussion throughout the study.

\section{References}

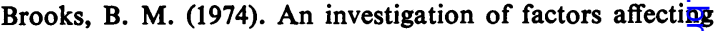
the use of buses by both elderly and ambulant disabled persons. Transport and Road Research Laboratory Caintract Report. British Leyland UK Ltd.

British Medical Journal (1978). Mobility and the disabled, 1, 672 .

Chamberlain, M. A., and Buchanan, J. (1978). Survey of the Mobility of the Disabled in an Urban Environment. Royal Association for Disability and Rehabilitation. 巂 press.

Duthie, J. J. R., Brown, P. E., Truelove, L. H., Baragar, F. R and Lawrie, A. J. (1961). Atti del X Congress della Lega Internazionale contra il Reumatismo, 1.

Eversley, D. (31 October 1977). Childless couples are twe planner's dream. The Guardian, 3.

Harris, A. (1971). Handicapped and Impaired in Gregt Britain, Part I. HMSO: London.

Jeffreys, M., Millard, M., and Warren, M. D. (1969). A set $\cdot$ of tests for measuring motor impairment in prevalence studie. Journal of Chronic Diseases, 22, 303-319.

Thompson, M., Anderson, M., and Wood, H. N. (197\$). Proceedings locomotor disease: a study of needs in on urban community. British Journal of Preventive and Social Medicine, 28, 70-71. 